\title{
KARAKTERISTIK PENGELOLA PROGRAM PENGENDALIAN PENYAKIT PNEUMONIA BALITA DI PUSKESMAS SE-KABUPATEN GIANYAR
}

\author{
Ni Kadek Ayu Srinadi*, I Made Sutarga \\ Program Studi Kesehatan Mayarakat Fakultas Kedokteran Universitas Udayana \\ *email: srinadi8@gmail.com
}

\begin{abstract}
ABSTRAK
Pneumonia merupakan bentuk terparah ISPA yang secara khusus menyerang paru-paru dan dapat menular dengan cepat. Pneumonia adalah penyakit yang disebabkan kuman pneumococcus, staphylococcus, streptococcus dan virus. Cakupan penemuan pneumonia di Kabupaten Gianyar 28,8\% sehingga masih dibawah target nasional sebesar $80 \%$ dengan permasalahan yang dihadapi yaitu deteksi kasus yang masih rendah karena belum adanya pelatihan untuk pengelola program pengendalian penyakit pneumonia dan perilaku pengelola program pneumonia dalam praktik penemuan kasus pneumonia memiliki peranan yang sangat penting sehingga perlu digambarkan karakteristik pengelola program pengendalian penyakit pneumonia di puskesmas se-Kabupaten Gianyar. Desain crossectional bersifat deskriptif yang dilakukan untuk menggambarkan karakteristik pengelola program pengendalian penyakit pneumonia balita di 65 puskesmas pembantu yang ada di Kabupaten Gianyar. Hasil penelitian menunjukkan sebagian besar responden berumur $<40$ tahun $(60,0 \%)$ dengan seluruh responden berjenis kelamin perempuan yang berpendidikan terakhir D3 (100,0\%). Selain itu, sebagian besar responden dalam penelitian tidak pernah mendapatkan pelatihan sebanyak $(96,9 \%)$ akan tetapi sebagian besar responden memiliki pengetahuan, sikap dan praktik yang baik atau sesuai standar. Diperlukan pelatihan yang serta keaktifan dalam mengikuti pelatihan tersebut.
\end{abstract}

Kata Kunci: Karakteristik pengelola program, pneumonia, Gianyar

\begin{abstract}
Pneumonia is the worst form of ISPA that specifically attack the lungs and can spread quickly. Pneumonia is a disease which are caused by microbe pneumococcus, staphylococcus, streptococcus and virus. The scope of pneumonia detection in Gianyar regency still below national target of $28,8 \%$ with the problem is faced which are case detection that is still low because there is no training for the worker of pneumonia control program and the behavior of the worker of pneumonia control program in practice of case pneumonia detection has an important role that make it is necessary to describe the characteristics of worker of pneumonia control program at health center in Gianyar regency. The study design in this study is descriptive crossectional design that done to describe the characteristics worker of toddler pneumonia control program at 65 auxiliary health center in Gianyar Regency. The results showed that the majority of respondents were $<40$ years old $(60,0 \%)$ with a history of D3 education of 65 people $(100,0 \%)$. In addition, most of the respondents in the study never received training as many as people $(96,9 \%)$ but most of the respondents had good or standard knowledge, attitudes and practices.Training is needed as well as active in participating in the training.
\end{abstract}

Key Word : Characteristics of managers program, pneumonia, Gianyar

\section{PENDAHULUAN}

Infeksi Saluran Pernapasan Akut (ISPA) merupakan infeksi yang terjadi pada setiap bagian dari sistem pernapasan mulai dari telinga tengah ke hidung sampai ke paru-paru (Hidayati, 2011). Pneumonia merupakan bentuk terparah ISPA yang secara khusus menyerang paru-paru dan dapat menular dengan cepat (Handayani,2012). Pneumonia 
adalah penyakit yang disebabkan kuman pneumococcus, staphylococcus, streptococcus dan virus (Cilloniz, 2016). Gejala penyakit pneumonia yaitu menggigil, demam, sakit kepala, batuk, mengeluarkan dahak dan sesak napas. Populasi yang rentan terserang pneumonia adalah anak-anak usia kurang dari lima tahun, usia lanjut lebih dari 65 tahun dan orang yang memiliki masalah kesehatan (malnutrisi, gangguan imunologi) (Sri Sundari, 2015).

Pneumonia merupakan penyebab utama kematian balita di dunia. Penyakit ini menyumbang $16 \%$ dari seluruh kematian anak di bawah 5 tahun, yang menyebabkan kematian pada 920.136 balita, atau lebih dari 2.500 per hari, atau di perkirakan 2 anak Balita meninggal setiap menit pada tahun 2015. Berdasarkan Data Riset Kesehatan Dasar Tahun 2018, didapatkan Prevalensi pneumonia meningkat dari $1,6 \%$ menjadi $2 \%$ untuk di Indonesia. Sedangkan untuk Provinsi Bali, prevalensi penyakit pneumonia yaitu sebesar 1,0\% (Kemenkes RI, 2018). ,0\% (Kemenkes RI, 2018).

Praktik penemuan kasus pneumonia yang dilakukan oleh pengelola program pengendalian penyakit pneumonia merupakan salah satu kegiatan inti dari program pengendalian penyakit pneumonia. Praktik penemuan kasus pneumonia dibedakan mejadi 2 yaitu praktik penemuan kasus secara aktif dan praktik penemuan kasus secara pasif. Praktik penemuan kasus secara aktif dilakukan dengan kunjungan ke masyarakat secara langsung oleh petugas puskesmas.

Masyarakat yang dinyatakan positif berdasarkan gejala klinis kemudian dilakukan konfirmasi laboratorium darah dan sputum serta hasil rontgen thorax. Data dari hasil konfirmasi laboratorium, rontgen dan pemeriksaan gejala klinis kemudian dikumpulkan untuk selanjutnya dikirim dan dilakukan analisis serta pelaporan data oleh pengelola program pengendalian penyakit pneumonia. Praktik penemuan kasus secara pasif dilaksanakan diseluruh puskesmas kabupaten/kota yang ada dengan melihat data jumlah penderita yang datang untuk berobat ke Unit Pelayanan Kesehatan (UPK) tersebut (Handayani, 2012).

Analisis data dilakukan berdasarkan kategori kelompok umur untuk mempermudah pengambilan kebijakan dalam rangka pengendalian dan pencegahan pneumonia. Data hasil analisis kemudian dilaporkan dalam bentuk laporan mingguan ke Kementrian Kesehatan yang diverifikasi oleh Dinas Kabupaten/Kota dan laporan bulanan dilaporkan ke Dinas Kesehatan Kabupaten/kota yang kemudian dikirimkan ke Dinas Kesehatan Provinsi, serta dilakukan umpan balik dan penyebarluasan informasi kepada publik berupa buletin, website dan laporan hasil kegiatan praktik penemuan kasus.

Praktik penemuan
memiliki peranan penting,
cakupan abila
pneumonia semakin besar, maka
kebijakan dapat cepat diputuskan serta
dapat diberikan pengobatan tepat dan


memutuskan penyebarannya yang cepat. Selain itu persentase cakupan penemuan kasus yang besar dapat membuat wilayah tersebut beberapa tahun kedepan bebas dari penyakit pneumonia (Handayani, 2012).

Tingginya prevalensi pneumonia menyebabkan pemerintah Indonesia membuat program pengendalian penyakit pneumonia dengan salah satu kegiatan inti dari program pengendalian penyakit pneumonia yaitu praktik penemuan kasus pneumonia. Berdasarkan data riskesdas tahun 2018, target nasional cakupan penemuan kasus pneumonia yaitu sebesar 80\% dan untuk Provinsi Bali cakupan pneumonia sesebar 58,35\%, hal ini menunjukkan bahwa angka cakupan yang dicapai provinsi Bali masih dibawah target nasional (Kemenkes RI, 2019).

Berdasarkan profil Kesehatan Provinsi Bali tahun 2017, Kabupaten Gianyar menempati urutan pertama dengan cakupan penemuan pneumonia terbanyak yaitu sebesar $28,8 \%$ dengan jumlah kasus sebanyak 287. Sedangkan menurut register pneumonia tahun 2018, jumlah kasus pneumonia balita sebesar 829 kasus dan pneumonia berat sebesar 3 kasus.

Berdasarkan studi pendahuluan yang dilakukan di Dinas Kesehatan Kabupaten Gianyar, tinggi rendahnya cakupan praktik penemuan kasus pneumonia disebabkan oleh pelatihan yang belum pernah diikuti serta perilaku dari pengelola program pneumonia yang pasif dalam praktik penemuan kasus pneumonia. Berdasarkan teori dari
Lawrence Green, perilaku seseorang dipengaruhi oleh faktor predisposisi (predisposing factors), faktor pendukung (enabling factors) dan faktor pendorong (renforcing factors). Program pegendalian penyakit akan berhasil apabila faktor predisposisi atau karakteristik, pengetahuan serta sikap dari petugas pengelola program pengendalian penyakit tersebut sudah baik.

Hal ini disebabkan faktor predisposisi merupakan faktor yang paling mendasari pembentukan perilaku (Widjanarko, 2006). Berdasarkan latar belakang permasalahan tersebut, penulis tertarik untuk menggambarkan Karakteristik Pengelola Program pengendalian penyakit pneumonia di puskesmas se-Kabupaten Gianyar.

\section{METODE PENELITIAN}

Desain penelitian dalam penelitian ini adalah desain crossectional bersifat deskriptif yang dilakukan untuk menggambarkan karakteristik pengelola program pengendalian penyakit pneumonia balita di 65 puskesmas pembantu yang ada di Kabupaten Gianyar. puskesmas se-kabupaten Gianyar yang dilakukan selama 3 bulan yakni dari Bulan Maret hingga Mei 2019.

Sampel dalam penelitian ini adalah pengelola program pengendalian penyakit pneumonia balita di 65 puskesmas pembantu yang ada di wilayah kerja Dinas Kesehatan Kabupaten Gianyar. Adapun kriteria inklusi diantaranya : pengelola program ISPA atau Pneumonia Puskesmas Pembantu di Kabupaten Gianyar dan yang bersedia menjadi 
responden. Penelitian ini merupakan penelitian crossectional bersifat deskriptif dengan pengambilan sampel yaitu total dari populasi yang sampelnya yang bersifat homogeny.

Analisis univariat adalah analisis yang digunakan untuk menjabarkan secara deskriptif variabel yang di teliti. Pada analisis ini akan diperoleh frekuensi dan persentase dari masingmasing variabel yang akan disajikan dalam bentuk tabel distribusi frekuensi.

\section{HASIL}

Tabel 1. Gambaran Karakteristik Responden

\begin{tabular}{|c|c|c|}
\hline Karakteristik Pengelola & Frekuensi (n) & Persentase $(\%)$ \\
\hline \multicolumn{3}{|l|}{ Umur } \\
\hline$<40$ tahun & 39 & 60,0 \\
\hline$\geq 40$ tahun & 26 & 40,0 \\
\hline \multicolumn{3}{|l|}{ Jenis Kelamin } \\
\hline Perempuan & 65 & 100,0 \\
\hline \multicolumn{3}{|l|}{ Pendidikan Terakhir } \\
\hline D3 & 65 & 100,0 \\
\hline \multicolumn{3}{|l|}{ Status Pelatihan } \\
\hline Pernah & 2 & 3,1 \\
\hline Tidak pernah & 63 & 96,9 \\
\hline \multicolumn{3}{|l|}{ Pengetahuan } \\
\hline Baik & 45 & 69,2 \\
\hline Kurang & 20 & 30,8 \\
\hline \multicolumn{3}{|l|}{ Sikap } \\
\hline Baik & 49 & 75,4 \\
\hline Kurang & 16 & 24,6 \\
\hline \multicolumn{3}{|l|}{ Praktik Penemuan kasus } \\
\hline Baik & 50 & 76,9 \\
\hline Buruk & 15 & 23,1 \\
\hline
\end{tabular}

Berdasarkan tabel 1, maka diketahui bahwa umur minimal dan maksimal responden yaitu 27 dan 55 tahun, serta sebagian besar responden berumur $<40$ tahun $(60,0 \%)$ dan seluruh $(100,0 \%)$ responden berjenis kelamin perempuan.
Sedangkan untuk variable pendidikan terakhir, seluruh $(100,0 \%)$ responden berpendidikan D3 dan (96,9\%) tidak pernah mendapatkan pelatihan. Pengetahuan dari responden, sebesar $(69,2 \%)$ responden memiliki pengetahuan 
baik. Selain itu, responden yang memiliki sikap baik sebesar $(75,4 \%)$ dan untuk praktik penemuan kasus pneumonia
$(76,9 \%)$ responden melaksanakannya dengan baik.

Tabel 2 Praktik Penemuan Kasus Pneumonia dengan Karakteristik Responden

\begin{tabular}{|c|c|c|c|c|c|c|}
\hline \multirow{3}{*}{ Variabel } & \multicolumn{6}{|c|}{ Praktik } \\
\hline & \multicolumn{2}{|c|}{ Baik } & \multicolumn{2}{|c|}{ Buruk } & \multicolumn{2}{|c|}{ Total } \\
\hline & $\mathbf{n}$ & $\%$ & $\mathbf{n}$ & $\%$ & $\mathbf{N}$ & $\%$ \\
\hline \multicolumn{7}{|l|}{ Umur } \\
\hline$<40$ tahun & 30 & 77,0 & 9 & 23,1 & 39 & 100,0 \\
\hline$\geq 40$ tahun & 20 & 77,0 & 6 & 23,1 & 26 & 100,0 \\
\hline \multicolumn{7}{|l|}{ Pelatihan } \\
\hline Pernah & 2 & 100,0 & 0 & 0,0 & 2 & 100,0 \\
\hline Tidak pernah & 48 & 76,2 & 15 & 23,8 & 63 & 100,0 \\
\hline \multicolumn{7}{|l|}{ Pengetahuan } \\
\hline Baik & 42 & 93,3 & 3 & 6,7 & 45 & 100,0 \\
\hline Kurang & 8 & 40,0 & 12 & 60,0 & 20 & 100,0 \\
\hline \multicolumn{7}{|l|}{ Sikap } \\
\hline Baik & 48 & 98,0 & 1 & 2,0 & 49 & $` 100,0$ \\
\hline Kurang & 2 & 12,5 & 14 & 87,5 & 16 & 100,0 \\
\hline
\end{tabular}

Berdasarkan Tabel 2, didapatkan hasil bahwa golongan umur $<40$ tahun, sebanyak $(77,0 \%)$ diantaranya memiliki praktik penemuan kasus pneumonia yang sesuai standar atau kategori baik. Sedangkan dari 26 responden yang berumur $\geq 40$ tahun, $(77,0 \%)$ respondennya melaksanakan praktik penemuan kasus pneumonia dengan baik.
Untuk riwayat pelatihan, pengelola program pengendalian penyakit pneumonia yang pernah mendapatkan pelatihan melaksanakan praktik penemuan kasus pneumonia secara baik atau sesuai standar $(100,0 \%)$ dan untuk pengelola program pengendalian penyakit pneumonia yang tidak pernah juga melaksanakan praktik penemuan 
kasus pneumonia secara baik atau sesuai standar sebesar $(76,2 \%)$.

Sedangkan dari 45 responden untuk yang memiliki pengetahuan baik, responden lebih banyak melaksanakan praktik penemuan kasus pneumonia secara baik atau sesuai standar sebesar (93,3\%) sedangkan pengetahuan responden yang kurang, diketahui bahwa $(60,0 \%)$ responden yang memiliki pengetahuan kurang melaksanakan praktik penemuan kasus pneumonia yang tidak sesuai standar atau kategori buruk dan untuk variabel sikap yang baik, (98,0\%) responden melaksanakan praktik penemuan kasus pneumonia dengan baik atau sesuai standar dan responden yang memiliki sikap kurang, sebanyak $(87,5 \%)$, melaksanakan praktik buruk.

\section{DISKUSI}

Karakteristik pengelola program pengendalian penyakit pneumonia variabel umur, hasil penelitian menunjukkan kedua kelompok umur melaksanakan praktik penemuan kasus pneumonia dengan baik atau sesuai standar. Umur akan mempengaruhi kekuatan fisik, namun dalam pelaksanaan praktik penemuan kasus pneumonia tidak memerlukan kekuatan fisik yang banyak karena dilakukan secara pasif sehingga tidak memperhitungkan umur dari Pengelola program pengendalian penyakit pneumonia khususnya dalam melaksanakan praktik penemuan kasus.
Hal ini sejalan dengan penelitian (Sudiar, 2013) menunjukkan bahwa umur tidak menunjukkan hubungan yang signifikan terhadap kinerja petugas klinik serta penelitian yang dilakukan oleh (Prabawa, 2016) bahwa tidak ada hubungan antara umur responden dengan praktik praktik penemuan Pneumonia Balita oleh Bidan.

Seluruh responden dalam penelitian ini berjenis kelamin perempuan yaitu 65 orang (100,0\%) melaksanakan praktik penemuan kasus pneumonia sesuai standar atau baik. Hal ini disebabkan karena jenis kelamin perempuan lebih teliti dan hati-hati dalam melakukan suatu pekerjaan termasuk dalam penemuan kasus pneumonia. Namun pada penelitian (Sudiar, 2013) menunjukkan bahwa jenis kelamin tidak menjukkan hubungan yang signifikan terhadap kinerja petugas klinik.

Karakteristik pengelola program pengendalian penyakit pneumonia variabel pendidikan terakhir, dengan kategori D3 melaksanakan praktik penemuan kasus pneumonia dengan baik. Seluruh responden berpendidikan D3 disemua puskesmas pembantu disebabkan karena banyak bayi maupun balita yang lebih memilih datang ke puskesmas pembantu dibandingkan puskesmas dengan alasan jarak dari pustu lebih dekat. Sehingga pemerintah lebih menempatkan yang berpendidikan D3 di puskesmas pembantu lebih khususnya tenaga Bidan dengan pendidikan terakhir D3. 
Pendidikan terakhir yang ditempuh pengelola program pengendalian penyakit pneumonia memberikan informasi mengenai kesehatan tanpa terkecuali mempelajari mengenai penyakit pneumonia serta tatalaksananya sehingga mampu melaksanakan praktik penemuan kasus dengan baik.

Hal ini sejalan dengan hasil penelitian yang dilakukan oleh (Sudiar, 2013) tingkat pendidikan seluruh petugas poliklinik S1 atau D III cenderung mempunyai kinerja yang baik. Hasil uji regresi logistik diperoleh nilai $\mathrm{p}=0,506>0,05$, yang artinya bahwa variabel tingkat pendidikan tidak berpengaruh secara signifikan terhadap kinerja.

Untuk meningkatkan informasi yang didapatkan oleh pengelola program pengendalian penyakit pneumonia di bangku kuliah, maka perlu diadakan kembali pelatihan maupun workshop di dunia kerja agar praktik penemuan kasus pneumonia dilaksanakan dengan baik. Pada penelitian ini didapatkan hasil bahwa baik responden yang mendapatkan pelatihan maupun yang tidak pernah mendapatkan pelatihan, sama-sama melaksanakan praktik penemuan kasus pneumonia dengan baik.

Hal ini disebabkan pengelola program pengendalian penyakit pneumonia dalam melaksanakan praktik penemuan kasus pneumonia dibantu dengan form Manajemen Terpadu Balita Sakit (MTBS) yang memuat langkah- langkah pemeriksaan pada balita dengan rinci sehingga pengelola program pengendalian penyakit pneumonia tidak mengalami kesulitan, baik untuk responden yang sudah mendapatkan pelatihan maupun yang belum mendapatkan pelatihan.

$\begin{array}{crr}\text { Tujuan } & \text { pelatihan ini yaitu } \\ \text { meningkatkan } & \text { pengetahuan dari }\end{array}$ pengelola program pengendalian penyakit pneumonia sehingga praktik penemuan kasus pneumonia dapat dilaksanakan dengan baik. Hasil penelitian menunjukkan bahwa responden yang memiliki pengetahuan kurang, melaksanakan praktik penemuan kasus pneumonia yang tidak sesuai standar atau kategori buruk sebesar $(60,0 \%)$. Sedangkan untuk yang memiliki pengetahuan baik, responden lebih banyak melaksanakan praktik penemuan kasus pneumonia secara baik atau sesuasi standar (93,3\%). Sehingga sejalan dengan teori pengetahuan atau kognitif merupakan hal yang sangat penting untuk membentuk tindakan seseorang, sebab perilaku yang didasari oleh pengetahuan lebih baik dibandingkan perilaku yang tidak didasari oleh pengetahuan (Rika, 2016).

Dalam langkah-langkah praktik penemuan kasus pneumonia, terdapat beberapa istilah yang harus dipahami seorang pengelola program pengendalian penyakit pneumonia sehingga pengetahuan yang baik akan membuat praktik penemuan kasus pneumonia juga baik atau standar apabila seorang pengelola program 
pengendalian penyakit pneumonia memiliki pengetahuan yang kurang, maka akan mengalami kesulitan dalam memahami maupun melaksanakan langkah-langkah praktik penemuan kasus pneumonia. Pengetahuan yang dimiliki akan mempengaruhi sikap dari pengelola program pengendalian penyakit pneumonia.

Secara nyata, sikap menunjukkan adanya hubungan antara reaksi dengan rangsangan yang diterimanya. Sikap dari pengelola program pengendalian penyakit pneumonia yang baik menghasilkan praktik yang baik. Sikap yang baik ini didukung oleh beberapa hal, salah satu contohnya sarana prasarana. Dalam melaksanakan praktik penemuan kasus pneumonia dibantu oleh stopwatch sehingga pengelola program pengendalian penyakit pneumonia tidak mengalami kesulitan dalam perhitungan nafas.

\section{Simpulan}

Umur minimal dan maksimal responden yaitu 27 dan 55 tahun, serta sebagian besar responden berumur $<40$ tahun $(60,0 \%)$, responden seluruhnya berjenis kelamin perempuan yaitu $(100,0 \%)$, seluruh pengelola program pengendalian penyakit pneumonia (100,0\%) pendidikan terakhirnya D3, sebesar $(96,9 \%)$ pengelola program pengendalian penyakit pneumonia tidak pernah mendapatkan pelatihan.

\begin{tabular}{l}
\multicolumn{4}{c}{ Pengetahuan dari $\begin{array}{r}\text { pengelola } \\
\text { program pengendalian }\end{array}$ penyakit } \\
pneumonia yaitu 45 orang $(69,2 \%)$
\end{tabular}

responden memiliki pengetahuan baik, sedangkan 20 responden (30,8\%) memiliki pengetahuan kurang, sikap pengelola program pengendalian penyakit pneumonia $(75,4 \%)$ memiliki sikap yang baik dan $(24,6 \%)$ memiliki sikap kurang yang baik sebesar $(76,9 \%)$ dan yang buruk $(23,2 \%)$. dan praktik penemuan kasus pneumonia

\section{SARAN}

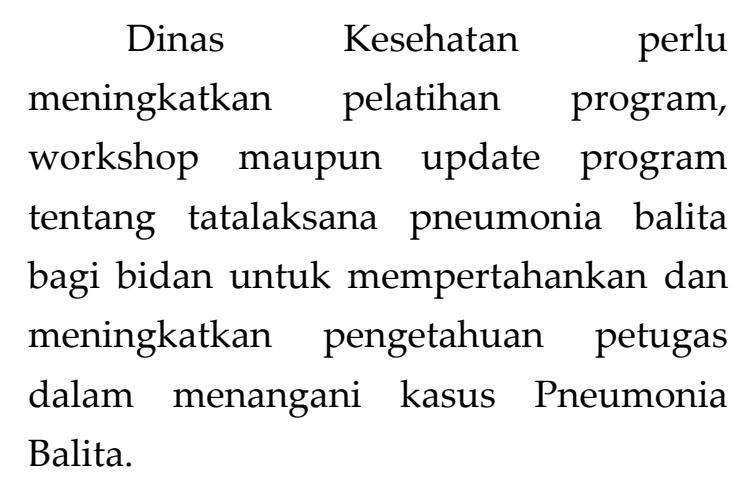

Saran bagi responden diharapkan aktif meningkatkan pengetahuan dan sikap melalui kegiatan pelatihan, workshop, seminar, dan pembinaan profesi. Selain itu meningkatkan penggunaan media KIE dalam pelayanan konseling kepada ibu dan keluarga.

\section{DAFTAR PUSTAKA}

Cilloniz, C. (2016). Microbial Etiology of Pneumonia: Epidemiology, International Journal of Molecular Sciences. 17(12) : 1-18.

Dinas Kesehatan Kabupaten Gianyar (2018). Profil Kesehatan Dinas Kabupaten Gianyar 2017. Gianyar. 
Dinas Kesehatan Provinsi Bali (2018). Profil Kesehatan Provinsi Bali Tahun 2017. Bali.

Handayani, R. P. (2012). Gambaran Kegiatan Penemuan Kasus Pneumonia Pada Balita di Puskesmas Se-Kota Semarang Tahun 2011. Jurnal Kesehatan Masyarakat, 1 (2) : 423-434.

Hidayati, A. N., \& Wahyono, B. (2011). Pelayanan Puskesmas Berbasis Manajemen Terpadu Balita Sakit Dengan Kejadian Pneumonia Balita. Jurnal Kesehatan Masyaraka,7 (1) : 35-40.

Kementrian Kesehatan RI. (2011). Pedoman Pengendalian Infeksi Saluran Pernafasan Akut. Jakarta: Kementrian Kesehatan RI.

Kementrian Kesehatan RI. (2018). Profil Kesehatan Indonesia Tahun 2017. Jakarta.

Prabawa, H. E. (2016). Faktor - Faktor Yang Berhubungan Dengan Praktik Penemuan Pneumonia Balita Oleh Bidan di Puskesmas
Wilayah Kabupatek Pemalang. [Skripsi]. Semarang: Universitas Negeri Semarang.

Rika. (2016). Hubungan Antara Pengetahuan dan Perilaku Pencegahan Gastritis Pada Mahasiswa Keperawatan. [Skripsi]. Makasar: Universitas Islam Negeri Alauddin Makassar.

Sri Sundari, F. T. (2015). Tingkat Pengetahuan Ibu Tentang Pneumonia Pada Balita Usia 1-5 Tahun. Bantul: Akademi Kebidanan Ummi Khasanah.

Sudiar, T. N. (2013). Pengaruh Karakteristik Individu Dan Kesejahteraan Karyawan Terhadap Kinerja Petugas Poliklinik Rs Pku Muhammadiyah Surakarta. Universitas Muhammadiyah Surakarta.

Widjanarko, B. (2006). Pengaruh Karakteristik, Pengetahuan Dan Sikap Petugas Pemegang. Jurnal Promosi Kesehatan Indonesia, 1(1) : 41-52. 